\title{
Human Trichinellosis in Argentina. REVIEW OF THE CASUISTRY REGISTERED FROM 1990 TO 1999
}

\author{
BOLPE J. \& BOFFI R.*
}

\section{Summary :}

Trichinellosis is an endemic disease in Argentina. During the last decade (1990 to 1999) 5,217 human cases were notified to the National System of Epidemiological Surveillance from

18 provinces of 23 that integrate the country. However $91 \%$ of the cases notified were registered in only three provinces (Buenos Aires, Cordoba and Santa Fel with a population of more than $50 \%$ of the inhabitants of Argentina. This data suggest the magnitude of trichinellosis as a public health problem, focalized in the central area of the country.

KEY WORDS : zoonosis, trichinellosis, epidemiology.

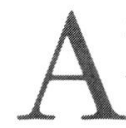
rgentina is located in the southern part of South America, the country has an area of almost 3.8 million square kilometers, of which 2.8 are on the continent and the remainder in the Antarctic. The current population is estimated to be some 35 million, of which almost half live in the Federal Capital and Buenos Aires Province (Instituto Nacional de Estadisticas y Censos 1991). The country is divided in 23 provinces.

Human trichinellosis is a common food borne disease, and annually in Argentina several outbreaks of the disease are registered, mainly during the winter season produced by the consumption of pigs or swine products from domestic slaughtering or slaughterhouse. Veterinary control of swine meat is obligatory in our country, therefore most outbreaks of the disease are caused by consumption of pigs an their derivates that escaped from sanitary inspection (Bolpe \& Caminoa, 1994; Costantino et al., 1993).

Infection in man may appear as isolated cases but frequently affecting different groups of people with a common source of infection, the illegal trade of cold meat and raw sausages and ham, etc., can spread trichinellosis in different areas of the country (Gonzalez Ayala, 1998). The present paper describes the casuistry of human trichinellosis in Argentina registered by the National Health Office during the period from 1990 to 1999.

\footnotetext{
* Departamento de Zoonosis Rurales. Ministerio de Salud Provincia de Buenos Aires, España 770 (7300) Azul, Argentina.

Tel.: 5402281422953 - Fax: 5402281424483.
}

\section{MATERIAL AND METHODS}

T $\mathrm{n}$ Argentina human cases of trichinellosis must be notified as quick as possible by doctors or hospital, to the Provincial and National health System according to the national law number 15465 of communicable diseases (Ministerio de Salud y Accion Social, 1994). We analyzed the data about human cases of trichinellosis registered in Argentina from 1990 to 1999, published by the National Epidemiological Surveillance Program that belongs to the National Ministry of Health, the conclusions of the First Trichinellosis National Meeting (year 1995), and the information of the disease obtained from the Ministry of Health of Buenos Aires province. The number of cases were classified by years and province of occurrence and the annual incidence rates per 100,000 habitants by year were estimated.

\section{RESULTS}

D uring the last decade (years 1990 to 1999) 5217 human cases of trichinellosis have been registered in Argentina, the distribution by provinces and years is detailed in Table I and Figure 1. Cases of the disease were notified in 18 of the 23 provinces. However most of them (91\%) occurred in three provinces, Buenos Aires, Cordoba and Santa Fe located in the center of the country; an area with a high population density in Argentina (50\% of the whole population of the country).

The annual incidence rates are presented in Table II. The human incidence increased, from 1993 to 1997, overcoming the level of two cases per 100,000 inhabitants by year in 1994/1997 and decreased in the last two years. Since 1994 the National health office has modified the surveillance of communicable diseases with new rules and proceedings (Ministerio de Salud y Accion Social, 1994), improving the information of communicable diseases not only in quantity but also in quality of human cases reported. 
Human cases by years

\begin{tabular}{|c|c|c|c|c|c|c|c|c|c|c|c|c|}
\hline Provinces & 1990 & 1991 & 1992 & 1993 & 1994 & 1995 & 1996 & 1997 & 1998 & 1999 & $\begin{array}{l}\text { Total } \\
\text { of the } \\
\text { decade }\end{array}$ & $\%$ \\
\hline Buenos Aires & 111 & 44 & 153 & 178 & 383 & 477 & 543 & 707 & 135 & 341 & 3,072 & 58.8 \\
\hline Córdoba & & 4 & 46 & 237 & 227 & 180 & 79 & 65 & 37 & 4 & 879 & 16.8 \\
\hline Santa Fe & & & & 3 & 387 & 60 & 124 & 157 & 68 & 20 & 819 & 15.8 \\
\hline Chubut & & & & 14 & 1 & & & & & 89 & 104 & 2 \\
\hline Río Negro & & & & & 7 & & 80 & 3 & & 4 & 94 & 1.8 \\
\hline San Luis & & & & & 1 & 1 & 10 & & 7 & 63 & 82 & 1.6 \\
\hline Neuquén & & & & 17 & 6 & 1 & & 8 & 3 & 24 & 59 & 1.1 \\
\hline Others provinces* & & & & 10 & 14 & 7 & 24 & 5 & 19 & 29 & 108 & 2.1 \\
\hline Total & 111 & 48 & 199 & 459 & 1,026 & 726 & 860 & 945 & 269 & 574 & 5,217 & 100 \\
\hline
\end{tabular}

* Capital Federal, Catamarca, Corrientes, Jujuy, La Pampa, La Rioja, San Juan, Tucumán, Santa Cruz, Santiago del Estero, Tierra del Fuego.

Table I. - Human cases of trichinellosis reported in Argentina from 1990 to 1999 distributed by years and provinces. National health office, 2000.

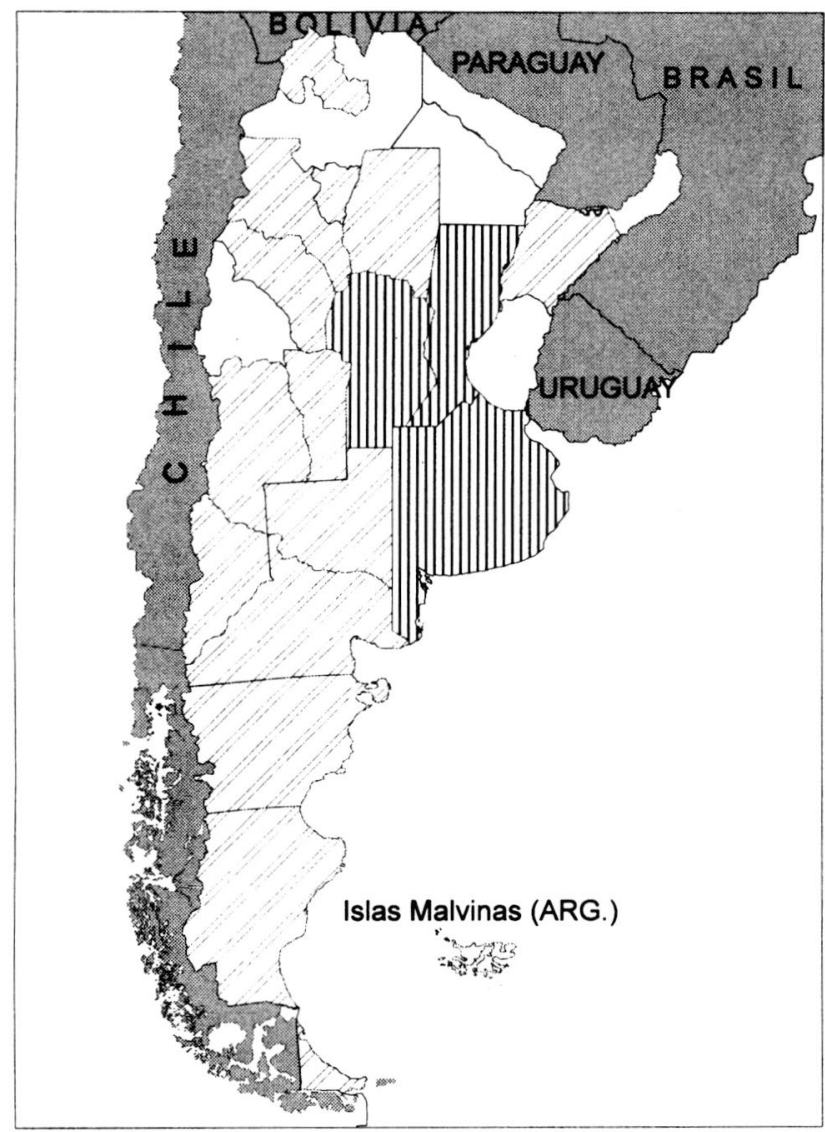

Provinces affected by the disease, low incidence with $8.6 \%$ of the notified human cases.

IIIII Geographical area with $91.4 \%$ of he human cases notified.

Fig. 1. - Trichinellosis in Argentina. Provinces with human cases registered from 1990 to 1999 . National health office.

\begin{tabular}{ccc}
\hline Years & $\mathbf{N}^{\circ}$ of cases & Rates $\mathbf{x . 1 0 ^ { 5 }}$ \\
\hline 1990 & 111 & 0.31 \\
1991 & 48 & 0.13 \\
1992 & 199 & 0.56 \\
1993 & 459 & 1.31 \\
1994 & 1,026 & 2.93 \\
1995 & 726 & 2.07 \\
1996 & 860 & 2.38 \\
1997 & 945 & 2.7 \\
1998 & 269 & 0.74 \\
1999 & 574 & 1.64 \\
\hline
\end{tabular}

Table II. - Annual incidence of human trichinellosis.

\section{DISCUSSION}

The results show that trichinellosis is an important public health problem in Argentina, focalized mainly in the center of the country. The increasing of annual incidence, mainly from 1994 to 1997, may have depended of a better epidemiological surveillance in the country, but other factors must be considered like: illegal trade of cold meat produced with infected pork, an increasing of domestic slaughtering without veterinary inspection, low efficacy of laboratory methods used for the detection of infected animals at slaughterhouses or domestic killing, habits and food education of the people.

Therefore it is necessary to develop a national control program of trichinellosis, based on the education of the consumers, regulating the commercial manufacture of pork products and improving the sanitary inspection at slaughterhouses. 


\section{REFERENCES}

Bolpe J. \& CAMINOA R. Triquinosis humana en la provincia de Buenos Aires Argentina. Reseña epidemiológica. RA.VE.TA. Boletín de vigilancia epidemiológica, 1994, 7 (1), 4-9.

Costantino S.N., Caminoa R., Ledesma M. \& Venturiello S. Outbreaks of domestic trichinellosis in Buenos Aires Argentina during 1992. Campbell W.C. et al., Trichinellosis, 1993, 511-514.

González Ayala S. Aspectos médicos de la Triquinosis. Temas de Zoonosis y enfermedades emergentes. II. Congreso Argentino de Zoonosis. I Congreso Argentino y Latinoamericano de enfermedades emergentes, 1998, 32-36.

Instituto Nacional de Estadísticas y Censos. Censo Nacional de Población y Vivienda 1991, Argentina, 1991, 28-32.

Ministerio de Salud y Acción Social, Argentina. R.M. n 394/94. SINAVE Sistema Nacional de Vigilancia Epidemiológica. Boletín Epidemiológico Nacional, 1994, 1, 3-25.

Soulé C. \& Dupouy-Camet J. La trichinellose, une zoonose en évolution. Paris : CNEVA-OIE, 1991, 292 p. 